\title{
The Economic Impact of Paraffin Type and Substrate Mixture on the Production of Grafted Vines-Case Study Muscat Ottonel
}

\author{
Anamaria Călugăr ${ }^{1}$, , Dan Corbean ${ }^{2}$, Nastasia Pop ${ }^{1}$, Claudiu Ioan Bunea ${ }^{1}$, \\ Anca Cristina Babeș ${ }^{1} \mathbb{D}$, Maria Iliescu ${ }^{3}$, Florin Dumitru Bora ${ }^{4}$ and Iulia Cristina Muresan ${ }^{5, *}(\mathbb{D}$ \\ 1 Viticulture and Oenology Department, Advanced Horticultural Research Institute of Transylvania, \\ Faculty of Horticulture, University of Agricultural Sciences and Veterinary Medicine Cluj-Napoca, \\ 3-5 Manastur Street, 400372 Cluj-Napoca, Romania; anamaria.calugar@usamvcluj.ro (A.C.); \\ nastasia.pop@usamvcluj.ro (N.P.); claudiu.bunea@usamvcluj.ro (C.I.B.); ancababes@usamvcluj.ro (A.C.B.) \\ 2 Jidvei Company, 45 Gării Street, 517385 Jidvei, Romania; dan.corbean@jidvei.ro \\ 3 Research and Development Station for Viticulture and Vinification Blaj, 2 Gh. Baritiu Street, \\ 515400 Blaj, Romania; iliescu.maria@scvblaj.ro \\ 4 Research Station for Viticulture and Enology Târgu Bujor, Department of Physico-Chemistry \\ and Biochemistry, 805200 Târgu Bujor, Romania; boraflorindumitru@gmail.com \\ 5 Department of Economic Sciences, University of Agricultural Sciences and Veterinary Medicine Cluj-Napoca, \\ 3-5 Manastur Street, 400372 Cluj-Napoca, Romania \\ * Correspondence: iulia.muresan@usamvcluj.ro
}

Received: 22 September 2020; Accepted: 14 October 2020; Published: 16 October 2020

\begin{abstract}
The study focussed on a nursery by analyzing its strategic choices to obtain the best profit on grapevine planting material. The production of grapevine grafts involves high labor and material costs. In this study, Muscat Ottonel grape variety grafted on Oppenheim Sellection 4 rootstock was paraffined with different types of wax: standard wax (SW), paraffin with 8-chinolinol (8C) and paraffin with oxiquinolein (OX) (before callusing), and silver color (S), blue color (B) and standard (SW) paraffin (after grafting callusing and before planting in field nursery). After uprooting from the field nursery, all variants were paraffined with red paraffin for storage. The unit cost price was calculated based on total expenses and the yield of grafts obtained in the vine field nursery. The lowest price per unit cost was recorded for the $8 \mathrm{C} / \mathrm{S}$ variant, directly related to the first quality yield after uprooting from the nursery. The highest profit rate was for the $8 \mathrm{C} / \mathrm{S}$ variant, while the lowest was registered to the SW/SW variant. The grafts of the $8 \mathrm{C} / \mathrm{S}$ variant were potted in three rooting mixtures. Variant B (forest ground $60 \%$ + black peat $25 \%$ + river sand $10 \%+$ conifer sawdust $5 \%$ ) generated the highest yield of the potted grafted vine with a rate of profit of over $170 \%$, due to the lower production cost and high yield of potted vines, while variant C (forest ground $70 \%+$ river sand $15 \%+$ conifer sawdust $15 \%$ ), determinate the lowest yield. Results may be useful in orienting the small-to-medium grapevine planting materials producers to choose the best cooperative strategies, which nurseries might implement to enhance their competitiveness and survive in the long-run.
\end{abstract}

Keywords: grapevine; paraffin; grafts; rooting substrate; price; profit rate

\section{Introduction}

Grapevine is an important crop from the economic point of view, cultivated in many areas around the world. Many times, markets dictate specific grapes that can be planted and sold, so the growers are interested in conferring particular traits in investment on the development of more resistant varieties to climate changes by grafting on rootstocks [1]. Grapevines are mainly propagated by vegetative 
methods from cuttings, from which, more than $80 \%$ are grafted vines [2]. In the last years, the global planting producing material and wine industry was transformed from small, traditionally oriented, family-owned enterprises to an industry dominated by multinational corporations [3]. Commercial grafting is practiced in many plant species, such as fruits, vegetables, and ornamentals, to obtain economic benefits [4,5]. Given the perennial nature of some horticultural crops (grapes especially), their high establishment costs, variability production in quality and prices, it is important to pay attention to risk management [6]. The individual component of risk management may be affected by price, yield, and product quality [7]. The level of those components is also influenced by the technology used to obtain a horticultural product. There are known many different ways to obtain a grafted grapevine $[7,8]$, but every step in the technology used (grafting, waxing, callusing, stratification and nursery), influences the price, and the profitability. Till now, in grapevine planting producing material there are some researches on different types of grafting [9], callusing conditions [10,11], stratification substrates [12,13] and nursery types, field or greenhouse [14] but few on paraffin types [15,16]. In current technologies, paraffin may be used in three stages: after grafting and before callusing (stage I), after callusing and nursery (stage II) and after nursery and before planting in the vineyard (stage III) [17]. Lately, the vine nurseries use more flexible microcrystalline paraffin (also called, waxes) produced by the petroleum refining process. All waxes have to fulfill some specifications such as melting point, congealing point, viscosity, needle penetration, oil content, and color [14].

During graft planting material production, some losses (2-50\%) occur in different stages (grafting, callusing, rooting, and uprooting from the nursery field) [18-20]. To increase the quality of grafts material, the hydroponic systems are used in greenhouses to minimize nursery losses [21]. From an economic point of view, the production of vines in pots should be less expensive, due to the shortening of the production cycle, respectively the rooting in the field nursery, phytosanitary treatments, irrigation, mechanical works, additional costs with labor, the surface of the land, different materials additional, and not least, of the last stage, uprooting from field nursery. Some of these stages continue to be carried out, at the definitive planting site, with the specific works and treatments specific to a vineyard.

Rooting media (chemical and physical characteristics) is an important factor for graft production in the greenhouse and directly affect graft quality and efficiency [22]. The rooting substrate must be easy to handle, free of weeds and pathogens, had good water capacity and drainage [23]. Due to its hydrological, physiochemical, and agronomic characteristics, peat is commonly used in the callusing stage after grafting [10,13], but also for rooting in pots or other containers [15]. For alternatives to peat utilization and to improve agricultural sustainability of rooting media, vineyard winter prunings, and grape stalks are valorized in nursery greenhouses for grapevine planting material production [24]. Rooting grafts in pots method had a high degree of intensity and require the complete assurance of the material base, complete and thorough knowledge of the technology, and its correct application. The production of grafted vines in nutritional pots includes a large number of agrotechnical links and requires a high volume of qualified works, justifying itself economically only in cases where a very valuable biological material is multiplied.

In Romanian agriculture, the vine and wine sector are one of the most developed sectors, mainly due to the full absorption of the funds for investments in new plantations, after the country accession to European Union in 2007. From a total of 182,849 ha planted with grapevine reported in 2015 was, almost half of the source was planted with interspecific hybrids temporarily accepted in culture [25]. The planting rights (about 13,000 ha) in various stages of usage, lead to a total viticultural potential of nearly 200,000 ha, according to [25]. Increasing the market potential for wine and grapes increased the demands for planting materials by the improvement and effective employment of techniques which allow the rapid expansion of propagating stock.

The grape plant materials have a high value mainly due to the competitive nature of the grape nursery business, but also of the rapid globalization of the grape and wine community. This results in some fundamental changes in the availability of some grape selections, varieties, and clones that are appropriate for the different climates in the world [26,27]. 
Grafting technology profitability may differ between different areas due to climatic conditions and pests, even when considering the same scions used. It is important to explore the issues in different technologies and compare the results obtained to provide useful information to the grafting producers. The main objective of the research was to determine the influence of the three types of paraffin (8-chinolinol (8C), oxiquinolein (OX), standard (SW) after callusing and three types (silver (S), blue (B), and standard (SW)) after field nursery and rooting in three different substrates, on the production of grafted vines for Muscat Ottonel. Based on economic data, the profitability rate was analyzed for each of the variants. The results are useful for grapevine material producers in adopting the right strategies to obtain the highest profit rate.

\section{Materials and Methods}

\subsection{Research Area}

The study was conducted during 2018 at the Jidvei Company, in Jidvei, Romania ( $46^{\circ} 13^{\prime} 20^{\prime \prime} \mathrm{N}$ $24^{\circ} 06^{\prime} 41^{\prime \prime}$ E, elevation $400 \mathrm{~m}$ ). Jidvei Company is the largest wine producer in Romania, with a total area of over 2500 ha of vines, it owns the largest vineyard plantation in the country and the largest vineyard with the sole owner in Europe. Also, Jidvei Company is the main grapevine planting producing material in the country, with 1.5-3 million grafts produce per year.

Jidvei is located in Tarnave Vineyard, in the north-western part of Romania, in the Transylvanian Plateau. The annual rainfall of the area is about $600 \mathrm{~mm}$ and the annual mean temperature is $10.2-10.4{ }^{\circ} \mathrm{C}$ [28]. The vineyard perimeter in this area is favorable for vine cultivation and quality white wines with DGO and GI especially dry, semi-sweet or sweet wines, semi-aromatic, aromatic wines, and sparkling wines [29].

\subsection{Research Methodology}

The study includes two experiments on Muscat Ottonel. The first experiment evaluates three paraffin used after grafting (standard, 8-chinolinol, and oxiquinolein), and two types of paraffin used after callusing and before planting in the nursery (blue and silver) on grafts rates, and their economic efficiency. The second experiment involved the analysis of the rooting substrate in pots on graft rates and its economic efficiency (Figure 1).

\subsubsection{Scions and Rootstock}

Muscat Ottonel is the representative aromatic wine for Târnave vineyard. In Romania is planted on $5.94 \%$ of total surface grapevine planted. Scions cuttings of Muscat Ottonel variety were harvested from mother plantation of graft canes of Jidvei Company during the previous fall. The scions cutting canes of 8 buds were kept till grafting at $2-4{ }^{\circ} \mathrm{C}$ and $90 \%$ humidity in cold rooms. Rootstock canes of Oppenheim Selection 4, clone 762 were imported from France (Pepiniers Tourette, Vogue).

\subsubsection{Grafting Technology and Paraffin Types}

Before grafting, rootstock canes were cut at $35 \mathrm{~cm}$ and scions at $5 \mathrm{~cm}(1 \mathrm{bud}-1 \mathrm{~cm}$ above the bud and $3 \mathrm{~cm}$ below the bud). Pre-grafting hydration and soaking propagation material (scions and rootstock) were made in tanks containing drench water and captan to reduced possible different pathogens infection. Hot treatment water was not applied, this procedure is not a common practice in Romanian grapevine nurseries.

Rootstock and scion were assembled with an omega-cut grafting machine in mid-April. Grafting machines were provided by Fornasier Cesare \& C. Snc (Rauscedo, Italy).

The paraffin used in this study were: paraffin with 8-chinolinol (8C), paraffin with oxiquinolein (OX) both containind hormones and fungicides and standard wax (SW), after grafting; paraffin of silver color (aluminum particles) (S), blue color (B), and standard wax (SW) used after callusing and before planting in the nursery (Table 1). After the field nursery harvest, red paraffin was used for the graft to 
protect due storage till planting. The paraffin was provided by La Compagnie Franco-Continentale des Lubrifiants, Bordeaux (France).

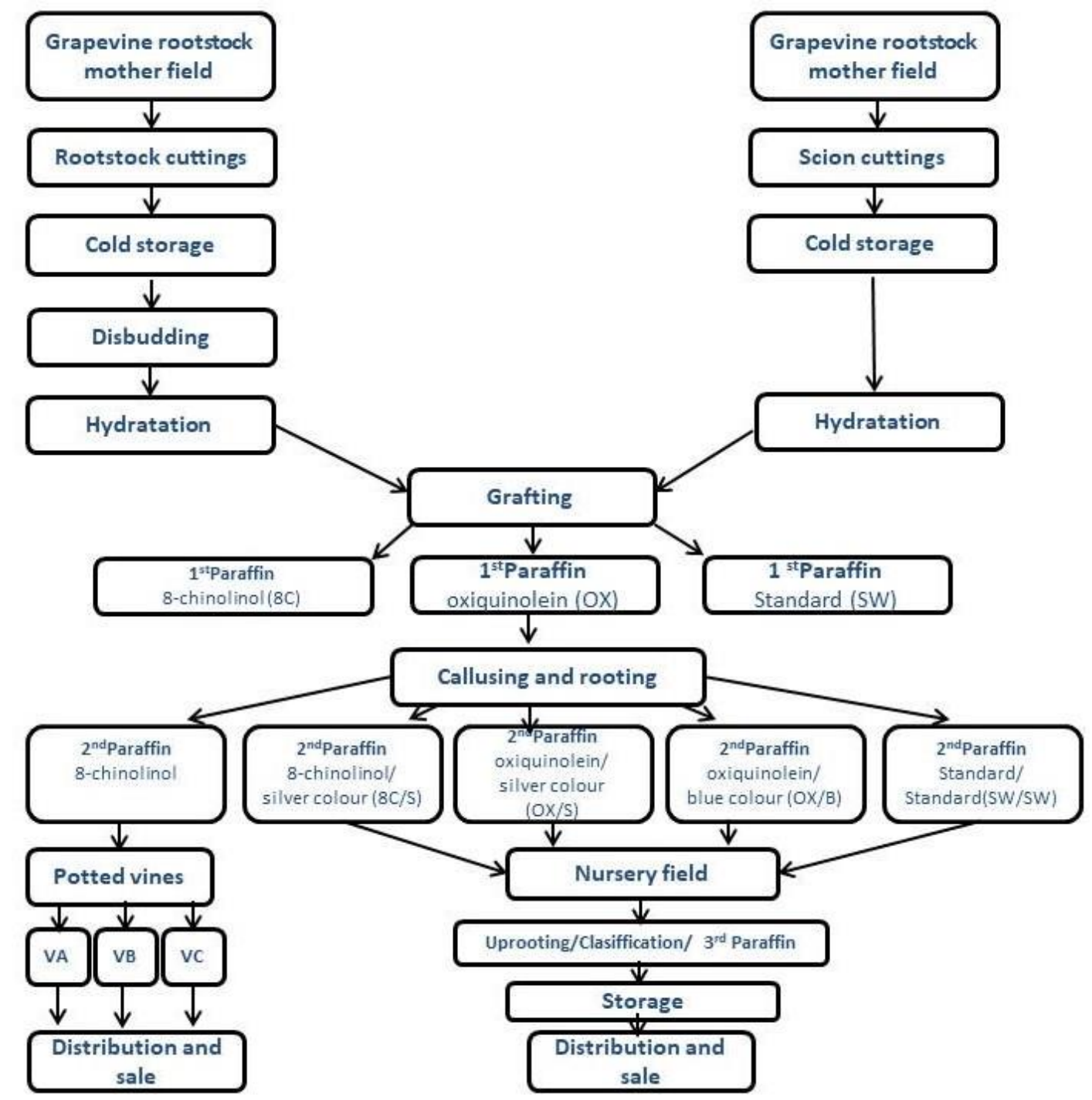

Figure 1. Experimental design. Note: VA: forest ground $50 \%+$ red peat $30 \%+$ river sand $15 \%+$ conifer sawdust $5 \%$; VB: forest ground $60 \%$ + black peat $25 \%+$ river sand $10 \%+$ conifer sawdust $5 \%$; VC: forest ground $70 \%$ + river sand $15 \%$ + conifer sawdust $15 \%$.

Table 1. Used paraffin in three stages and experimental design.

\begin{tabular}{|c|c|c|c|c|c|}
\hline Stage & \multicolumn{5}{|c|}{ Type of Paraffin } \\
\hline $\begin{array}{l}\text { After Grafting, } \\
\text { before Callusing } \\
\text { (Stage I) }\end{array}$ & \multicolumn{2}{|c|}{ 8-Chinolinol (8C) } & \multicolumn{2}{|c|}{ Oxiquinolein (OX) } & \multirow{2}{*}{$\begin{array}{l}\text { Standard (SW) } \\
\\
\text { Standard } \\
\text { (SW) }\end{array}$} \\
\hline $\begin{array}{l}\text { After callusing, } \\
\text { before } \\
\text { planting in nursery } \\
\text { (stage II) }\end{array}$ & Silver color (S) & Blue color (B) & Silver color $(S)$ & Blue color (B) & \\
\hline $\begin{array}{l}\text { After nursery, } \\
\text { before storage } \\
\text { (stage III) }\end{array}$ & Red color (R) & Red color $(\mathrm{R})$ & Red color (R) & Red color $(\mathrm{R})$ & $\begin{array}{l}\text { Red color } \\
\text { (R) }\end{array}$ \\
\hline
\end{tabular}




\subsubsection{Callusing Technology}

Stratification was made with pine sawdust (from local sources), wetted and disinfected with a concentration of $0.01 \% \mathrm{CuSO}_{4}$. Grafts were vertically positioned in wooden boxes walls lined with porous polyethylene film. The exchange of humidity and temperature between inside and outside the box was provided by the polyethylene sheet. The capacity of a box is about 2000 grafts.

After filling, boxes were covered with a thin canvas with $30 \mathrm{~g} / \mathrm{m}^{2}$ density (Idromeccanica Lucchini SpA, Guidizzolo, Italy) (Figure 2a), over which was placed a $5 \mathrm{~cm}$ layer of wet sawdust (Figure 2b). In the first three days, the temperature rose from 10 to $32{ }^{\circ} \mathrm{C}$, then went down to $30^{\circ} \mathrm{C}$, keeping constant until the end of the callusing (14th day) (Table 2).

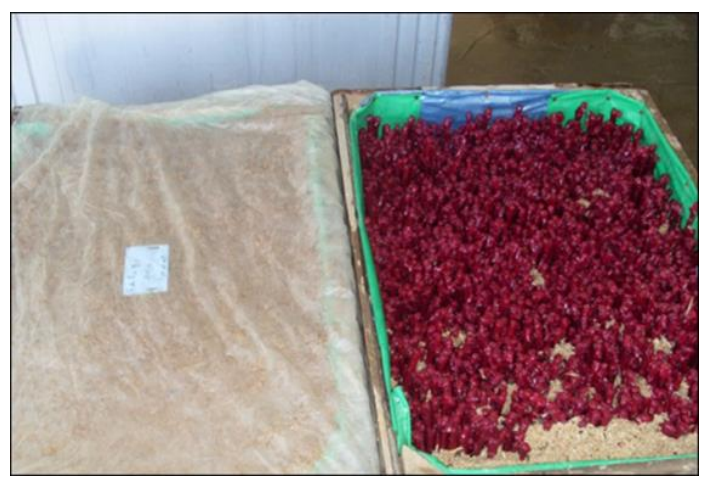

(a)

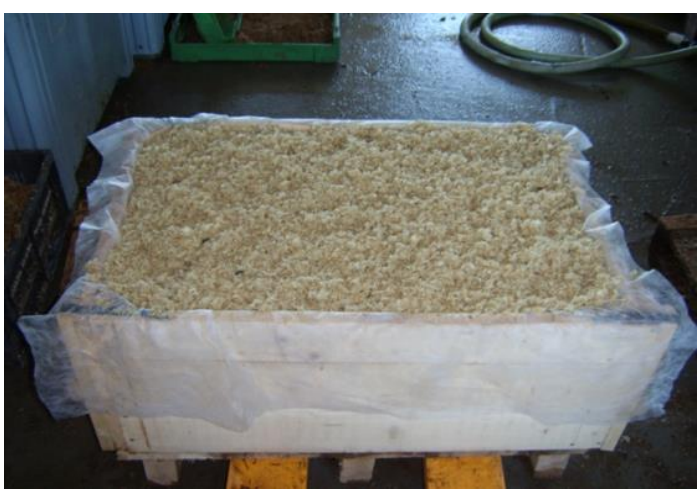

(b)

Figure 2. Callusing boxes with sawdust substrate (a), covered with Geotextil canvas, and a layer of $5 \mathrm{~cm}$ on sawdust (b).

Table 2. Evolution of temperature and air humidity during callusing.

\begin{tabular}{|c|c|c|c|c|c|c|c|c|c|c|c|c|c|c|}
\hline \multirow{2}{*}{$\begin{array}{c}\text { Period } \\
\text { Day }\end{array}$} & \multicolumn{3}{|c|}{ First 3 Days } & \multicolumn{11}{|c|}{ Next 11 Days } \\
\hline & 1 & 2 & 3 & 4 & 5 & 6 & 7 & 8 & 9 & 10 & 11 & 12 & 13 & 14 \\
\hline Temperature ${ }^{\circ} \mathrm{C}$ & \multicolumn{3}{|c|}{$10-32$} & \multicolumn{11}{|c|}{30} \\
\hline Air humidity \% & \multicolumn{3}{|c|}{$65-85$} & \multicolumn{11}{|c|}{$75-80$} \\
\hline
\end{tabular}

Air humidity in the first three days was rose from $65 \%$ to on a high level of $85 \%$ (Table 2). After this first stage, marked at the beginning of the formation of callus mass at the grafting point, it has decreased to $75-80 \%$ and remained constant until the end of forcing. The layer of sawdust over boxes were kept till the end of callusing, so the grafts forcing was made without light. During callusing, phytosanitary treatments were made immediately after grafting placing into the box to avoid the attack of Botrytis cinerea and saprophytic fungal species of the genus Fusarium provided by Syngenta Crop Protection AG, (Basel, Switzerland). At the end of callusing, grafts were classified in two categories: Category I and inadequate [30]. Category I grafts (NGFC) have new well defined and formed formations (callus around grafting point, shoots, roots), measured and appreciated according to Celik et al. [31]. For each variant, five repetitions of 500 grafts were counted, resulting in 2500 grafts per variant of paraffin type.

$$
\text { GYC } \%=[\text { NGFC/NGS }] \times 100
$$

where: GYC = Grafted Yield after Callusing (\%); NGFC = Number of Grafted vines in First Category; NGS $=$ Number of Grafted Scions.

\subsubsection{Vine Field Nursery}

Grafts from Category I (NGFC) were chosen to be planted in the field nursery. Before planting, grafts were secondarily paraffined with paraffin (silver-S and blue-B) and standard (SW). After the 
second paraffin layer, grafts were put again in wood boxes with a $3-5 \mathrm{~cm}$ layer of water, in a solarium covered with a green sheet for acclimatization for two weeks. The field nursery was located at Jidvei village on a plane land with a sandy loam structure protected from cold airstreams and floods [14].

The experience in the vine nursery was set up in randomized blocks of experiments. For each variant, five repetitions of 500 grafted vines were made, resulting in 2500 vines per paraffin combination.

At the end of May, grafts were manually planted in earthlings up wrapped in black polyethylene sheets. Polyethylene sheet and fertigation system were provided by Chauvin (Saint-Jean-de-Moirans, France). The polyethylene sheet was double rowed at $37 \mathrm{~cm}$ between holes and $3.5 \mathrm{~cm}$ on the row (50 holes per meter), resulting in the planting density of 250,000 grafts/ha. Nursery management consisted of five phytosanitary treatments, $2-3$ shoots thinning, fertigation, and grafts uprooting in the mid of November.

After uprooting, each graft was verified before the third layer of paraffin. Category I of grafted vines (GYFN\%) and inadequate was set up based on the measurements and observations made on grafted vines (length and diameter of the cane, number, and size of roots, degree of grafting).

After classification, canes were trimmed at 2-3 buds, paraffined with preservation red paraffin. After the third layer of paraffin, grafts were stored at $2-4{ }^{\circ} \mathrm{C}$ till spring for selling or planting.

$$
\text { GYFN } \%=[\mathrm{NGFC} / \mathrm{NGV}] \times 100
$$

where: GYFN = Grafted Yield after Field Nursery (\%); NGFC = Number of Grafted vines in First Category; NGV = Number of Grafted Vines planted in the field nursery.

\subsubsection{Potted Vine in Solarium Nursery}

After the second layer of paraffin, 30,000 grafts of variant 8C/S were manually transferred into Fertil pot pressed cardboard $(7 / 9 / 11 \mathrm{~cm})$ provided by Fertil (Boulogne-Billancourt, France). The pots were filled with three different soil mixtures from local sources. Each soil mixture variant was 10,000 pots, arranged in a randomized design with 10 replicates/variant.

Variant A-Forest ground 50\% + Red peat 30\% + River sand 15\% + Conifer sawdust 5\% = $247 \mathrm{~g} /$ pot

Variant B-Forest ground $60 \%+$ Black peat $25 \%+$ River sand $10 \%+$ Conifer sawdust $5 \%=$ $274 \mathrm{~g} /$ pot

Variant C-Forest ground 70\%+ River sand 15\% + Conifer sawdust 15\% $=323 \mathrm{~g} /$ pot

The highest weight of mixing pots was in variant $C$, where the percentages of forest ground $(70 \%)$ and sand $(15 \%)$ were higher than the variants $\mathrm{A}$ and $\mathrm{B}$.

Rooting grafts in Fertil Pot were made in a tunnel greenhouse covered with plastic foil with followed dimensions (width-6 m, length-50 m, height-4 m). The pots were put on perforated polyethylene foil on the ground over a drainage layer $(5 \mathrm{~cm}$ depth) of gravel $(0.5-1 \mathrm{~cm}$ diameter) and clean river sand. Inside the greenhouse tunnel, was appointed 4 alleys, of $1.2 \mathrm{~m}$ width and a passing aisle between alleys of $60 \mathrm{~cm}$ width. The delimitation of the alleys where pots were placed was made of concrete slabs with the square section with the side of $8 \mathrm{~cm}$, which ensures good lateral stability of the alleys. The verification of the solariums consisted of the verification of the irrigation system, the verification of the covering sheet, the tracing of the layers on which the pots are placed. To prevent excessive heating inside, they were covered with a protective mesh.

The planting of vines was done in the greenhouse, with the base in the nutritional mixture on a depth of 5-6 cm. Immediately, after planting, the pots were watered with $15-20 \mathrm{~L} / \mathrm{m}^{2}$ water to ensure the contact of the grafts with the rooting mixture.

During the rooting period of grafted vines in nutrient pots, the temperature, in the first week after planting was maintained at $25-30{ }^{\circ} \mathrm{C}$, then, lowered to $20-22{ }^{\circ} \mathrm{C}$. The hygroscopicity of the air remained around $85 \%$ during the first two weeks, until the appearance of the first leaves, then lowered 
to approx. $60 \%$. On hot days, when the humidity of the airdropped below $50 \%, 2-3$ artificial watering systems, of short duration, were made [14].

The moisture content of the nutrient mixture in the pots was maintained within optimal limits of $28-30 \%$ of the weight of the rooting mixture, by repeated watering, avoiding the excess moisture in the pots, which can cause root suffocation. Root and foliar fertilization were made with water-soluble fertilizers based on nitrogen, phosphorus, potassium, and with micro-elements provided by Groupe Roulier (Saint-Malo, France).

The control of diseases and pests was carried out by weekly treatments with contact and systemic products provided by Syngenta Crop Protection AG (Basel, Switzerland). The grafts were classified according to root appearance and root output from the pot, growth vigor of grafted vines-shoot length $(\mathrm{cm})$ and diameter $(\mathrm{mm})$.

$$
\text { GYPV } \%=[\mathrm{NGFC} / \mathrm{NGVP}] \times 100
$$

where: GYPV $=$ Grafted Yield of Potted Vines (\%); NGFC = Number of Grafted vines in First Category; NGVP = Number of Grafted Vines planted in Pots.

After four weeks of fortification, all the shoots started from the rootstocks were removed. The grafts in the pots where the growths of the shoots were at least $20 \mathrm{~cm}$ long and with a minimum of $4 \mathrm{~mm}$ diameter, were selected to be planted in the vineyard.

ANOVA (Analysis of Variance) and LSD (Least Significance Difference) test were used to calculate the significant difference between the variants and the mean of experience of yield grafted grapevine and potted vines. The interaction between variants and the mean of experience was evaluated at $95 \%$, $99 \%$, and $99.9 \%$ to determine the significance. The statistical interpretation of the results was made using SPSS Version 24 (SPSS Inc., Chicago, IL, USA).

\section{Results and Discussions}

\subsection{Paraffin and Cutting Price}

The aspects studied are related to the influence of the type of paraffin on production, graft yield, and production costs with a direct impact on the cost per unit of product, but also on economic efficiency.

The cost of the paraffin requirement was given by the price of paraffin, but also by the use of paraffin needed to wax a grafted vine. Paraffins with growth hormones and fungicides had a consumption of about $2 \mathrm{~g} /$ grafted vines ( $8 \mathrm{C}$ and OX, respectively), the standard, silver and bleu paraffins had a consumption of $3 \mathrm{~g} / \mathrm{grafted}$ vine due to the higher viscosity, while the standard paraffin and the paraffin used for storage, $4 \mathrm{~g} / \mathrm{grafted}$ vine (Table 3).

Table 3. Consumption on grafts, paraffin and biological material prices.

\begin{tabular}{ccc}
\hline Paraffin Type & $\begin{array}{c}\text { Consumption on Grafts } \\
\text { (g/graft) }\end{array}$ & $\begin{array}{c}\text { Price } \\
\text { (euro/kg) }\end{array}$ \\
\hline Paraffin with 8-quinolinol (8C) & 2 & 4.23 \\
\hline Parafina with oxiquinolein (OX) & 2 & 4.71 \\
\hline Standard paraffin (SW) & 3 & 1.61 \\
\hline Paraffin of silver color (S) & 3 & 2.43 \\
\hline Paraffin of blue color (B) & 3 & 4.16 \\
\hline Paraffin of red color for preservation (R) & 4 & 1.60 \\
\hline Biologic material一grafts scion (1 bud) & Price (euro/bud) \\
\hline Buds grafts of Muscat Ottonel & 0.023 \\
\hline Biological material一rootstock canes & Price (euro/cane) \\
\hline Rootstock canes (1.07 m length/rootstock cane) & 0.130 \\
\hline
\end{tabular}




\subsection{Callusing and Grafts Yield}

In the process of callusing, paraffin plays a particularly important role, and by its composition, it must not inhibit the formation of new formations. Under the influence of the excitation of injury, in the presence of hormonal substances, under favorable ecological conditions, the meristematic cells on the surface of the section as well as those of the immediately adjacent layers, begin to divide intensely, and with this, the formation of the callus (parenchymal tissue with undifferentiated cells) starts, a fundamentally new tissue, also called wound tissue [32,33]. The callus should be moderate and uniformly formed around the grafting point, if it is too abundant, it overflows, pushing the gravel upwards, if it is too weakly formed, it does not ensure good vascularization [34,35]. The results obtained by Wunderer and Schmuckenshlager [36] showed a better calibration following the use of paraffin, compared to the binding point with Parafilm and Kambasian (elastic synthetic material), which is mainly due to the weak oxygenation of the two sections.

Excessive proliferation of new cell tissue (callus) is not beneficial in the process of welding the two partners (graft and rootstock) due to the unnecessary consumption of reserve substances (carbohydrates) [37,38].

A critical role in the formation of the callus is the temperature during the forcing, so that the high temperatures (higher than $30^{\circ} \mathrm{C}$ ) favor the formation of a fragile callus, easily damaged during subsequent manipulations and leading to the separation of the partners. Particular importance must be given to the type of paraffin used to avoid blocking the conducting vessels (xylem and phloem) and then the defective welding of the two grafting partners [34,39].

After 14 days of callusing, the classification of grafted vines was made in two categories: Category I and inappropriate. Grafted vines form Category I must have callus, shoots, roots well defined and shaped. The best results recorded for the Muscat Ottonel variety in terms of grafted paraffined vines in Category I (GYC\%) were obtained for the variant 8C (76.74\%), significantly higher than the mean experience, while the lowest yield was recorded for the SW variant (55.7\%). The presence of different stimulator in paraffin composition increase the grafts yield after callusing (Table 4).

Our results are comparable with those obtained by Cara [40], in Moldova, following the treatment of grafted vines (Cabernet Sauvignon grafted on Kober 5 BB, omega mechanized) with the growth stimulator Calovit obtained between 70-78, 6\% grafted vines after callusing. Burlacu et al. [41], obtained a percentage of callusing of $96 \%$ using Rebwachs paraffin (with 8 quinolinol) and $88 \%$, using standard paraffin improved with dichlorbenzoic acid $(0.001 \%)$.

Table 4. Grafts yield after callusing (\%) and after nursery uprooting (\%).

\begin{tabular}{|c|c|c|c|}
\hline \multicolumn{2}{|c|}{$\begin{array}{l}\text { The Yield of Grafted Paraffined Vines } \\
\text { from Category I, } \\
\text { after Callusing } \\
\text { GYC } \%(n=5)\end{array}$} & \multicolumn{2}{|c|}{$\begin{array}{l}\text { The Yield of Grafted Paraffined Vines } \\
\text { from Category I, } \\
\text { after Extracting from the Vine Nursery } \\
\text { GYFN } \%(n=5)\end{array}$} \\
\hline \multirow{2}{*}{ 8-quinolinol (8C) } & \multirow{2}{*}{$76.74 \pm 1.28^{* * *}$} & $8 \mathrm{C} / \mathrm{S}$ & $75.60 \pm 0.86^{* * *}$ \\
\hline & & $8 \mathrm{C} / \mathrm{B}$ & $65.00 \pm 1.41^{\mathrm{ns}}$ \\
\hline \multirow{2}{*}{ Oxyquinolein (OX) } & \multirow{2}{*}{$68.73 \pm 0.77^{* *}$} & OX/S & $68.40 \pm 0.36^{* * *}$ \\
\hline & & $\mathrm{OX} / \mathrm{B}$ & $62.40 \pm 0.93^{\circ o 0}$ \\
\hline Standard (SW) & $55.70 \pm 0.99$ oоo & SW/SW & $55.00 \pm 0.66^{\text {ooo }}$ \\
\hline Mean & 67.05 & & 65.28 \\
\hline LSD $5 \%$ & 0.93 & & 0.93 \\
\hline LSD $1 \%$ & 1.54 & & 1.27 \\
\hline LSD $0.1 \%$ & 2.89 & & 1.75 \\
\hline
\end{tabular}

Values are expressed as mean \pm standard deviation ${ }^{*}, \mathrm{o}: p<0.05 ;{ }^{* *}$, oo: $p<0.01$; ${ }^{* * *}$, ooo: $p<0.001$; ns: not significant. 
Iliev et al., [16] recorded 90-92.5\% of grafted vines after callusing for Storgozia (local variety) grafted on $\mathrm{SO}_{4}$ rootstock, testing Aktigref, Rebvaks VF, and Proaktigref. Teker et al., [42] using paraffin (name or other characteristics not mention) obtained the highest graft ratio, after callusing, for Cardinal on 5 BB (80.00\%) and Michele Palieri on 1103 P (78.33\%).

As mentioned in Materials and Methods, after the first classification, a second paraffin layer (stage II) was applied with the silver (aluminum particle) and blue color, to which fungicides have been added. The grafts were put in wood boxes in a $10 \mathrm{~cm}$ sawdust layer. The boxes were kept under solarium covered in a shading net for two weeks. Planting in the field vine nursery was done manually in the third decade of May. During the vegetation period, all variants have benefited from the same treatments (phytosanitary, irrigation, fertilization, soil, and canopy management). The uprooting from the vine nursery was done mechanically in mid-November. The management of the vine nurseries aims to obtain the highest percentage of grafted grapevines of Category I, which must fulfill all conditions in terms of growth and rooting.

The classification of the grafted vines after uprooting was made according to the quality conditions which impose $100 \%$ biological purity; complete welding around the grafting point, the length of the main cane with the matured wood of at least $15 \mathrm{~cm}$, the thickness of the cane at the second internode of at least $4 \mathrm{~mm}$ for the rooted grafts in the nursery, the length of the rootstock at least of $35 \pm 2 \mathrm{~cm}$; a root number of at least three roots with a diameter of $2 \mathrm{~mm}$ and length at least $15 \mathrm{~cm}$ [30].

The yield of grafted vines of Category I (GYFN\%) after uprooting, recorded for the variants $\mathrm{C} / \mathrm{S}$ and $\mathrm{OX} / \mathrm{S}$ paraffin were higher, 75.6 , and $68.4 \%$ respectively, compared to the variants $8 \mathrm{C} / \mathrm{B}$ and $\mathrm{OX} / \mathrm{B}$ (65\% and $62.40 \%$, respectively). Grafted vines of Category I of four variants of paraffin were superior to variant SW/SW which only yielded 55\% (Table 4). Our results are higher than those obtained by Terek et al., [42], with grafted rooted vines yield of $44.4 \%$ (Rebvaks VF) after uprooting from the nursery, and 30-35\% (Actygref and Proactygref, respectively), although the callusing had higher values than results in our experiment.

\subsection{Economic Analysis of the Grafted Vines from the Field Nursery}

Based on the accounting data, the economic efficiency for each variant of paraffin used for Muscat Ottonel grafts was calculated for one hectare of field nursery.

Due to the data regarding material expenditure, costs of the biological material, paraffin, and labor, but also the yield of quality vines obtained after callusing and after uprooting, the cost per unit was calculated (for grafted vine) for each paraffin variant $(8 \mathrm{C} / \mathrm{S}, \mathrm{OX} / \mathrm{S}, 8 \mathrm{C} / \mathrm{B}, \mathrm{OX} / \mathrm{B}$, and SW/SW).

Based on the cost of a vine before planting in the field nursery and the number of vines that can be planted per hectare (250,000 grafts/ha), the production costs of planting material has been calculated.

The low callusing rate after stratification caused higher costs of biological material (scion buds and rootstock) for the SW variant. Although the price of SW paraffin was twice lower than $8 \mathrm{C}$ and OX paraffin, in the end, the material costs for this variant were higher, around 80,288 euros.

The labor cost included the harvest of scions buds from mother scion vine, deposit till mechanized grafting, paraffining, maintenance during callusing, sorting, second paraffining, planting and maintenance in field nursery, uprooting from field nursery, sorting and the third paraffining, and the deposit of grafted vine till selling or planting. During April, the mean air temperature in Jidvei is around $11^{\circ} \mathrm{C}$, so it involves high energy cost to maintain a temperature of $30^{\circ} \mathrm{C}$ in the callusing room. The method of callusing used in Jidvei, described in the Materials and Method section, shorts the callusing period to 14 days, so, the energy cost is reduced.

It can be noticed that the material was third times higher than labor costs. Even if the price of SW paraffin was half the price of the others, because of the low yield of grafted vines $55.70 \%$ after callusing (GYC \%) and after uprooting from field nursery (55\%) (GYFN\%), the labor costs per one hectare, have exceeded variant $8 \mathrm{C} / \mathrm{S}, 8 \mathrm{C} / \mathrm{B}, \mathrm{OX} / \mathrm{S}$, and $\mathrm{OX} / \mathrm{B}$.

The cost of production was calculated based on the expenses and the graft yield. The lowest cost per product unit (grafted vine) was recorded for $8 \mathrm{C} / \mathrm{S}$ (8-quinolinol/silver paraffin), of 0.59 euro/grafted 
vine, directly related to the yield of $75.60 \%$ for Category I (GYFN\%). The highest cost per unit was for the SW/SW variant, of 0,87 euro/grafted vine, due to the lower yield of grafted vines (Table 5).

The selling price of the grafted vine may vary depending on variety, grade, and economic aspects. According to Waite et al., [3] at the level of 2017, the selling price for a grafted vine was very different, from 0.90 euro in Hungary, 1.30-1.50 euro in Austria, 1.40-1.65 euro in France, 1.55 euro in Germany, $1.50-1.60$ euro in Italy, 1.00-1.50 euro in South Africa, 1.40-1.65 euro in Spain to 2.72-3.00 euro in Australia, 3.00-3.10 euro in New Zealand, 3.16-4.36 euro in Switzerland and 3.20-5.00 euro in the USA.

Table 5. Economic efficiency indicators depending on paraffining variants at Muscat Ottonel variety, at Jidvei Company.

\begin{tabular}{cccccc}
\hline Variant of Paraffin & \multirow{2}{*}{$\mathbf{8 C / S}$} & $\mathbf{8 C / B}$ & OX/S & OX/B & SW/SW \\
\cline { 1 - 5 } Manual labour cost (euros/ha) & $26,030.47$ & $25,863.10$ & $26,799.32$ & $26,704.59$ & $28,021.87$ \\
\hline Total production cost (euros/ha) & $111,441.50$ & $112,492.61$ & $116,060.29$ & $117,271.37$ & $119,141.35$ \\
\hline Yield grafts (NGFC no./ha) & 189,000 & 162,500 & 171,000 & 156,000 & 137,000 \\
\hline Cost price (euros/grafted vine) & 0.59 & 0.69 & 0.68 & 0.75 & 0.87 \\
\hline Selling price (euros/grafted vine) & & & 1.37 & & $188,157.89$ \\
\hline Revenue (euros/ha) & $258,631.58$ & $222,368.42$ & $234,000.00$ & $213,473.68$ & $69,013.50$ \\
\hline Profit (euros/ha) & $147,189.28$ & $109,875.81$ & $117,939.69$ & $96,202.31$ & 6 \\
\hline
\end{tabular}

Although the vines were different paraffined, the grafted vine classified in I Category (NGFC), for all variants, the selling price per unit was 1.37 euro, lower than most European countries. The highest profit rate was $132.08 \%$ for variant $8 \mathrm{C} / \mathrm{S}$ (8-quinolinol/silver). The lowest profit rate of $57.92 \%$ was for SW/SW, mainly due to the low graft yield after callusing and after uprooting from field nursery (Figure 3).

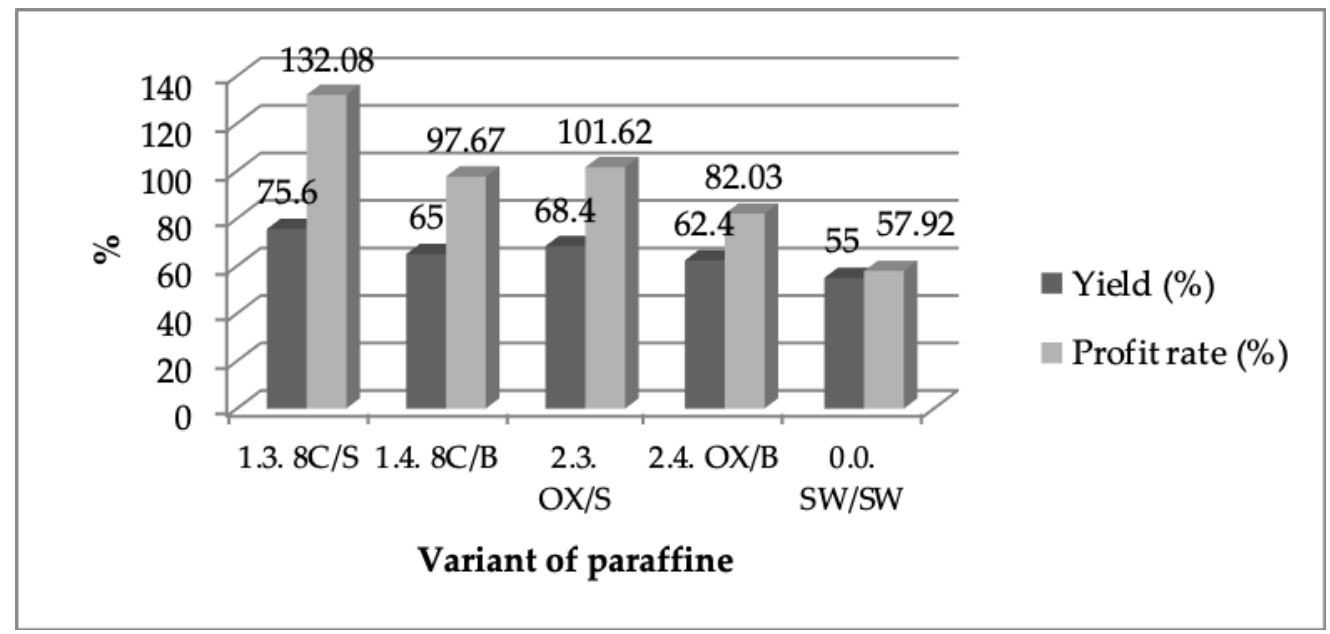

Figure 3. Profit rate and yield depending on the variant of the paraffin for Muscat Ottonel grafted vines.

\subsection{Economic Analysis of Potted Grafted Vines Data}

In the second part of the research, the grafts used for rooting in Fertile pots with the different nutritional mix were those from variant $8 \mathrm{C} / \mathrm{S}$ (Figure 1). The 8C/S variant was choosen for rooting in different substrates mixtures due to the highest GYC \% (76.74\%) after callusing and the best GYFN \% $(75.60 \%)$ after field nursery. Potted vines are grafted and dispatched in the same year. The production of vines in nutritious pots is necessary for the newly established plantations during summer, but also to replant dead vines in the young vineyards. The vigor and efficiency of the planting are related to the 
support, respectively the nutritional pot which consists of stimulants existing in the rooting substrate, but also the phase fertilization that starts from planting in the pot, until planting in the vineyard [14]. Potted vines could be a good solution to establish a vineyard one season quicker than dormant vines, in warmer areas. Potted vines need more attention than a dormant vine when planting, and during their management for the first season. Watering is essential for potted vines as they are planted during summer when new, tender plants need the most nutrition.

The 35-40 day period, after the second layer of paraffin has been applied, is considered sufficient to obtain potted vines ready to be planted in the vineyard. Fertil Pot pots made of pressed cardboard have the property of optimum water retention in the soil mixture and allow the roots to easily penetrate the cardboard casing. This type of cardboard ensures good resistance, is not destroyed due to the humidity or during the transport period, it decomposes in the ground after one month after planting [43].

The soil mixture must be relaxed to allow carbon dioxide release and oxygen access. The ratio between the gap space and the solid parts of the mixture should be 4:1, as opposed to a soil of the chernozem type (which contains a high percentage of humus), where this ratio is usually 1:1. If the nutrient mixture is stained and excessively humid, phenols and polyphenols form at the base of the vines, as a result of carbon dioxide stagnation, appearing on the bark and freely blue-violet or even black and smell of mud. In these cases, no roots appear, and the root of the rootstock, necroses, and vines are lost [10].

The yield obtained is directly influenced by the quality of the biological material used (scions and rootstocks), by the ecological conditions (temperature, humidity, ventilation) of the solarium, by the nutrient substrate for rooting, by the phytosanitary substances, and the rooting stimulants. All these factors have the role of reducing the stress of vines when planting in pots [12,14].

Becker [44] shows that in the case of cultivating grafted vines in nutrient pots, when using peat and sand mixtures, the yield in good grafted vines to be planted is higher as the percentage of peat is higher. Thus, using pure peat, the yield was $56 \%$, and when pure sand was used, the yield was only $12 \%$.

Zamanidis et al. [45] used for the rooting of grafted vines (Rkatsiteli grafted on rootstocks 5 BB and 101-14) different nutrient substrates: soil, pearlite, sawdust; rice bran + fallow + sand (1:1:1); peat + fallow + sand (1:1:1); loose soil + fallow + sand (1:1:1), the percentages of vines good for planting are satisfactory in all variants.

The vigor of the shoot is very important for obtaining a quality vineyard planting material. This is conditioned by the content in reserve substances of the two partners [37,46], the degree of nutrition of the rooting substrate [20] and, the fertilization in the vine school [47]. In the experience, the foliar and root fertilization were used equal doses and concentrations for the three variants, the influence being only of the soil mixture.

The lack of vegetation in the shoots is influenced by different technological factors: too short thinning of the shoot after removal from the callusing chamber, burns caused by the second layer of paraffin, and physiological: low content of reserve substances in both the graft and the rootstock [48].

In this regard, it should be mentioned that the texture of the rooting mixture is influenced by the quality of the peat. The rooting mixture for variant B, having a lighter texture, drainage and, permeability of the water of upper irrigation, facilitates heat exchange of medium-pots. The lighter texture also creates aeration of the rooting mix, excluding the possibility of infestation of roots with different species of saprophytic fungi that can be installed at the root level leading to the decay and death of the plant (Rosellinia necatrix, Armillaria mella) [49,50]. After 40 days of rooting, were analyzed the influence of the three variants of the nutritional mix on rooting and growth of shoots, and finally on yields. The results showed that the best yield GYPV\% was obtained in the black peat variant $(89.1 \%)$, followed by the red peat variant $(85.4 \%)$, and the lowest yield was obtained in the C variant $(75.8 \%)$, which consisted of only forest land, river sand, and fir sawdust.

Based on the expenses with the necessary materials in the production technology of grafted vines in nutritional pots and the obtained yields, the cost price per unit of the product was calculated. 
The analysis of the economic efficiency was made starting from the cost price obtained for the vines destined for planting in the pots ( 0.26 euro/grafted vine). The composition in different proportions in the nutritious mixture of peat (red, black), sand, fallow, and sawdust gave different costs to the three variants. The costs of human labor (preparing the rooting mixture, laying the drain bed, filling the pots with the rooting substrate, wetting the pots, planting vines in the pots, irrigating and performing phytosanitary treatments, but also some works on the plant) were equal for the variants with peat. It can be mentioned that, due to the greater weight of the pots in variant $C$, they were handled more difficult and needed more labor days (Table 6).

Table 6. Economic data of potted vines.

\begin{tabular}{|c|c|c|c|}
\hline Variant & Variant A & Variant B & Variant C \\
\hline Expenses Elements & $\begin{array}{c}\text { Euro/10,000 } \\
\text { Potted Vines }\end{array}$ & $\begin{array}{c}\text { Euro/10,000 } \\
\text { Potted Vines }\end{array}$ & $\begin{array}{c}\text { Euro/10,000 } \\
\text { Potted Vines }\end{array}$ \\
\hline $\begin{array}{l}\text { Grafts paraffined with variant }(8 \mathrm{C} / \mathrm{S}) \\
\text { (8-quinolinol/silver paraffin) }\end{array}$ & 2607.94 & 2607.94 & 2607.94 \\
\hline Fertil Pot pots & 1286.54 & 1286.54 & 1286.54 \\
\hline Forest soil & 22.45 & 29.83 & 41.09 \\
\hline Black peat & - & 116.20 & - \\
\hline Red peat & 124.63 & - & - \\
\hline River sand & 19.47 & 13.68 & 25.26 \\
\hline Conifer sawdust & 4.47 & 5.21 & 17.88 \\
\hline Water for pots wetting & & 2.43 & \\
\hline $\begin{array}{l}\text { Water for irrigation and } \\
\text { phytosanitary treatments }\end{array}$ & & 29.71 & \\
\hline Sand for draining bed & & 9.09 & \\
\hline Soluble fertilizers & & 59.30 & \\
\hline Labour (60 NDL) & \multicolumn{2}{|c|}{1263.16} & 1326.32 \\
\hline Fixed fonds amortized & \multicolumn{3}{|c|}{90.95} \\
\hline Overall expenses & 4966.36 & 4960.26 & 4900.19 \\
\hline Quality vine yield GYPV\% $(\mathrm{n}=10)$ & $85.40 \pm 2.10$ * & $89.10 \pm 1.26^{* * *}$ & $75.80 \pm 1.26^{\text {ooo }}$ \\
\hline Cost price (lei/pcs) & 0.65 & 0.62 & 0.73 \\
\hline Selling price & \multicolumn{3}{|c|}{1.68} \\
\hline Income from selling & $14,347.20$ & $14,968.80$ & $12,734.40$ \\
\hline Profit & 8827.07 & 9454.77 & 7217.29 \\
\hline Profit rate \% & 159.91 & 171.47 & 130.82 \\
\hline Mean quality vine yield \% & \multicolumn{3}{|c|}{83.10} \\
\hline LSD 5\% & \multicolumn{3}{|c|}{1.79} \\
\hline LSD 1\% & \multicolumn{3}{|c|}{2.88} \\
\hline LSD $0.1 \%$ & \multicolumn{3}{|c|}{3.92} \\
\hline
\end{tabular}

$\mathrm{NDL}=$ Normated Day Labour (8 h/day); Values of GYPV $\%$ are expressed as mean \pm standard deviation * $\mathrm{o}: p<0.05$; **, oo: $p<0.01 ; * * *$, ooo: $p<0.001$.

The yield of quality grafts GYPV\% was different due to different cost prices between the three variants. The lowest cost production ( 0.62 euro/potted vine) was obtained when the rooting substrate was $60 \%$ woodland, black peat $25 \%$, sand $10 \%$, sawdust $5 \%$ (variant B), followed by the cost price of variant $\mathrm{A}$ ( 0.65 euro/potted vine), and the highest cost price was obtained in variant $C$ ( 0.73 euro/potted vine), the variant in which the nutritional mixture was from forest land $70 \%$, sand $15 \%$, sawdust $15 \%$. 
Although the overall expenses for variant $C$ were lower than the other two variants, the higher cost price for variant $C$ was due primarily to the low yield of quality vines $(75.8 \%)$ recorded by this variant (Table 6).

The selling price was considered equal for each variant, of 1.68 euro/potted vines. Generally, the price of the potted vine is higher than grafted vine from field nursery [51]. Following the sale, variant B generated a rate of profit of $171.47 \%$. Variants A and C, variants at which the cost price was higher, encounter a profit rate of over $100 \%$ (159.91\% for variant A and $130.82 \%$ for variant B).

Potted vines should be planted early enough to benefit from a long growing season rather than suffer from a short one. The season should be sufficiently long for the vine to develop self-supporting root and shoots and develop frost-tolerant wood before the winter season [52]. At planting, the root system should fill the pot and have an active shoot tip growth with a good basal caliper.

\section{Conclusions}

The superior results obtained by combining the two types of paraffin are because that one favors quenching (paraffin with 8-quinolinol) and the other is to reject solar radiation from both the sun and the black foil through the aluminum particles of the composition.

Comprehension of the success of the graft yield after the forcing stage is important to the evaluation of the suitable grafting for the open field (nursery). The success of grafting in plants (grapevines) requires the development of a functional vascular system between the scion and the rootstock. The graft compatibility and its augmentation depend upon various natural factors like environment, soil conditions, and protective measures.

Some propagators may say they receive a low price for grafted vines, so for nurseries is important to adopt practices designed to obtain high yielded grafts and a low production cost.

The improved propagation practices that rise grafts quality, compensate any additional cost of production, and will not threaten the viability of planting material businesses.

The cost of good quality grafted vines is amortized during the life of the vineyard.

As a general rule, dormant vines are preferable to green-potted vines. This is because it is far easier to inspect the quality of dormant plants (as roots and graft unions can be readily examined) and because dormant vines do not suffer transplant shock, commonly associated with late summer and heat spike planting of green vines.

The study focussed on a nursery with a specific business model and a strategic edge by analyzing its strategic choices to obtain the best profit on grapevine planting material. Within this case study, a financial ratio analysis, which was based on 2018 financial statements, was conducted to analyze the profitability of the grafted and potted vines. Research limitations/implications: This study has territorial limitations, but Jidvei company generally plays an important role in the regional and Romanian grafted grapevine producers. This research may be considered as an exploratory study, deserving further investigation into different strategic choices within the company system by performing cross-case comparisons. Results may also be useful in orienting cooperative strategies in Romania to small-to-medium grapevine planting materials producers, often lacking specific abilities relating to the distribution, marketing and selling of their grafts. Originality/value: The authors contend that their study provides hitherto missing information relating to different strategic materials choices, which nurseries might implement to enhance their competitiveness and survive in the long-run.

Author Contributions: Conceptualization, A.C. and I.C.M.; methodology, D.C.; software, F.D.B. and I.C.M.; validation, N.P., C.I.B. and A.C.B.; formal analysis, M.I.; investigation, A.C.; resources, D.C.; data curation, M.I.; writing-original draft preparation, A.C.; writing-review and editing, I.C.M.; visualization, C.I.B.; supervision, A.C.B.; project administration, D.C. All authors have read and agreed to the published version of the manuscript.

Funding: The publication was supported by funds from the National Research Development Projects to finance excellence (PFE)- 37/2018-2020 granted by the Romanian Ministry of Research and Innovation.

Acknowledgments: The authors wish to thank Jidvei Company for allowing them to use the financial data on which the analysis has been developed. 
Conflicts of Interest: The authors declare no conflict of interest.

\section{References}

1. Zhang, L.; Marguerit, E.; Rossdeutsch, L.; Ollat, N.; Gambetta, G.A. The influence of grapevine rootstocks on scion growth and drought resistance. Theor. Exp. Plant Physiol. 2016, 28, 143-157. [CrossRef]

2. Ollat, N.; Peccoux, A.; Papura, D.; Esmenjaud, D.; Marguerit, E.; Tandonnet, J.P.; Bordenave, L.; Cookson, S.J.; Barrieu, F.; Rossdeutsch, L.; et al. Rootstocks as a component of adaptation to environment. In Grapevine in a Changing Environment: A Molecular and Ecophysiological Perspective, 1st ed.; Gerós, H., Ed.; Wiley: Oxford, UK, 2016; pp. 68-108.

3. Waite, H.; Armengol, J.; Billones-Baaijens, R.; Gramaje, D.; Halleen, F.; Di Marcom, S.; Smart, R. A protocol for the management of grapevine rootstock mother vines to reduce latent infections by grapevine trunk pathogens in cuttings. Phytopathol. Mediterr. 2018, 57, 384-398.

4. Nawaz, M.A.; Huang, Y.; Bie, Z.; Ahmed, W.; Reiter, R.J.; Niu, M.; Saba, H. Melatonin: Current status and future perspectives in plant science. Front. Plant Sci. 2016, 6, 1230. [CrossRef] [PubMed]

5. Pozzan, M.S.V.; Braga, G.C.; Salibe, A.B. Teores de antocianinas, fenóis totais, taninos e ácido ascórbico em uva 'Bordô' sobre diferentes porta-enxertos. Rev. Ceres 2012, 59, 701-708. [CrossRef]

6. Zinnanti, C.; Schimmenti, E.; Borsellino, V.; Paolini, G.; Severini, S. Economic performance and risk of farming systems specialized in perennial crops: Analysis of Italian hazelnut production. Agric. Syst. 2019, 176, 102645. [CrossRef]

7. Waite, H.; Whitelaw-Weckert, M.; Torley, P. Grapevine propagation: Principles and methods for the production of high-quality grapevine planting material. N. Z. J. Crop. Hortic. 2015, 43, 144-161. [CrossRef]

8. Sabri, A. Comparison of Green Grafting Techniques for Success and Vegetative Development of Grafted Grape Cultivars (Vitis Spp.). Int. J. Agric. Biol. 2011, 13, 628-630.

9. Marín, D.; García, R.; Eraso, J.; Palacios, J.; Santesteban, L.G. Evaluation of nursery success rate of four grapevine grafting techniques alternative to omega graft. In Proceedings of the 22nd Int'l Geisenheim Conference on Grapevine Propagation, Geisenheim, Germany, 28-30 June 2018.

10. Aroca, Á.; Gramaje, D.; Armengol, J.; García-Jiménez, J.; Rapos, R. Evaluation of the grapevine nursery propagation process as a source of Phaeoacremonium spp. and Phaeomoniella chlamydospora and occurrence of trunk disease pathogens in rootstock mother vines in Spain. Eur. J. Plant Pathol. 2010, 126, 165-174. [CrossRef]

11. Köse, B.; Çelik, H.; Karabulut, B. Determination of callusing performance and vine sapling characteristics on different rootstocks of 'Merzifon Karası' grape variety (Vitis vinifera L.). Anadolu J. Agric. Sci. 2015, 30, 87-94. [CrossRef]

12. Cookson, S.J.; Clemente Moreno, M.J.; Hevin, C.; Mendome, L.Z.N.; Delrot, S.; Trossat-Magnin, C.; Ollat, N. Graft union formation in grapevine induces transcriptional changes related to cell wall modification, wounding, hormone signalling, and secondary metabolism. J. Exp. Bot. 2013, 64, 2997-3008. [CrossRef]

13. Assunção, M.; Santos, C.; Brazão, J.; Eiras-Dias, J.E.; Fevereiro, P. Understanding the molecular mechanisms underlying graft success in grapevine. BMC Plant Biol. 2019, 19, 396. [CrossRef] [PubMed]

14. Corbean, D.G. New Technologies for Producing Grapevine Planting Material, in Târnave Vineyard. Ph.D. Thesis, University of Agricultural Science and Veterinary Medicine, Cluj Napoca, Romania, 2011.

15. Corbean, D.; Pop, N.; Babeş, A.C.; Călugăr, A.; Bunea, C.; Moldovan, S.D. Research regarding the influence of rooting subtrate in fertile pots on yield of grafted vines, at S.C.; Jidvei, S.R.L, Târnave Vineyard. Lucr. Ştiinţ. Ser. Hortic. 2011, 54, 449-454.

16. Iliev, A.; Dimitrova, V.; Peykov, V.; Prodanova-Marinova, N. Technological investigations for improvement of grapevine propagation material production in Bulgaria. Part, I. Results of affinity study and comparative testing of paraffins in the production of grafted rooted vines. TURKJANS 2014, 1, 1274-1279.

17. Călugăr, A.; Corbean, D.G.; Pop, T.I.; Bunea, C.I.; Iliescu, M.; Babes, A.C.; Chiciudean, G.O.; Mureșan, I.C. Economic efficiency of the use of different paraffins to obtain Fetească regală grapevine grafts. In Proceedings of the Multidisciplinary Conference on Sustainable Development, Timișoara, Romania, 28-29 June 2019.

18. Abo Rehab, M.E.A.; Korra, A.K.M.; Kamhawy, M.A.M.; Youssef, K.Y.A. Fungal species associated with graft union on grapevine, its impact on graft failure process and attempted solutions in Egypt. Int. J. Agric. For. 2013, 3, 52-59. [CrossRef] 
19. Borgo, M.; Calo, A.; Costacurta, A.; Gardiman, M.; Malacchini, G. La propagation rapide de la vigne par microgreffage ISV Conegliano. Riv. Vitic. Enol. 1998, 51, 3-14.

20. Bruna, E.D.; Back, Á.J. Comportamento da cultivar Niágara Rosada sobre diferentes porta-enxertos no sul de Santa Catarina. Brasil. Rev. Bras. Frutic. 2015, 34, 924-933. [CrossRef]

21. Şengel, E.A. Research on the Effects of Three Different Rooting Material on the Quality and Yield on Tubed Grape Graft Production under the Conditions of Hydrophonic Culture Methods. Master's Thesis, Ege University Science Institute, Bornova, Turkey, 2005. Unpublished (In Turkish).

22. Sengel, E.; Isci, B.; Altindisli, A. Effects of Different Culture Media on Rooting in Grafted Grapevine. Ege Üniv. Ziraat Fak. Derg. 2012, 49, 143-148.

23. Rajkumar, R.; Gora, J.S.; Kumar, R.; Singh, A.; Kumar, A. Effect of different growing media on the rooting of pomegranate (Punica granatum L.) cv. 'Phule arakta' cuttings. J. Appl. Nat. Sci. 2017, 9, 715-719. [CrossRef]

24. Ronga, D.; Francia, E.; Allesina, G.; Pedrazzi, S.; Zaccardelli, M.; Pane, C.; Tava, A.; Bignami, C. Valorization of Vineyard By-Products to Obtain Composted Digestate and Biochar Suitable for Nursery Grapevine (Vitis vinifera L.) Production. Agronomy 2019, 9, 420. [CrossRef]

25. Antoce, A.O.; Călugăru, L.L. Evolution of grapevine surfaces in Romania after accession to European Union-Period 2007-2016. In Proceedings of the BIO Web of Conferences, 40th World Congress of Vine and Wine, Sofia, Bulgaria, 29 May-2 June 2017; Volume 9, p. 03018. [CrossRef]

26. Omer, A.D.; Granett, J.; Kocsis, L.; Downie, D.A. Preference and performance responses of California grape phylloxera to different Vitis rootstocks. J. Appl. Entom. 1999, 123, 341-346. [CrossRef]

27. Pathirana, R.; McKenzie, M.J. A modified green-grafting technique for large-scale virus indexing of grapevine (Vitis vinifera L.). Sci. Hortic. 2005, 107, 97-102. [CrossRef]

28. Bora, F.D.; Dina, I.; Iliescu, M.; Zaldea, G.; Guță, I.C. Analysis and Evaluation of the Main Ecoclimatic Conditions from Romanian Vineyards. Bull. UASVM Hortic. 2016, 73, 221-223.

29. Călugăr, A.; Babeș, A.C.; Bunea, C.I.; Pop, T.I.; Tomoiagă, L.; Iliescu, M. Oenological characterization of wines from grape clones created at Research Station for Viticulture and Oenology Blaj, Romania. Ştiinţ. Agric. 2018, 2, 50-56.

30. Council Directive 68/193/EEC of 9 April 1968 on the Marketing of Material for the Vegetative Propagation of the Vine In force: This Act Has Been Changed. Latest Consolidated Version: 14/07/2005. Available online: https://eur-lex.europa.eu/legal-content/RO/TXT/PDF/?uri=CELEX:31968L0193\&from=EN (accessed on 14 August 2020).

31. Celik, H.; Odabas, F. The effects of the grafting time and types on the success of the grafted grapevine production by grafting under nursery conditions. Turkish J. Agric. For. 1998, 22, 281-290.

32. Hunter, J.J.; Volschenk, C.G.; Le Roux, D.J.; Fouche, G.W.; Adams, L. Plant Material Quality-a Compilation of Research; Research Reports; ARC-INR Infruitec-Nietvoorbij: Stellenbosch, South Africa, 2004.

33. Jogaiah, S.; Oulkar, D.P.; Banerjee, K.; Sharma, J.; Patil, A.G.; Maske, S.R.; Somkuwar, R.G. Biochemically induced variations during some phenological stages in Thompson Seedless grapevines grafted on different rootstocks. S. Afr. J. Enol. Vitic. 2013, 34, 37. [CrossRef]

34. Rashedy, A.A. Effect of pre-grafting incubation and grafted cuttings positionon grape grafting success. Egypt. J. Hort. 2016, 43, 225-240.

35. El-Gendy, R.S.S. Evaluation of flame seedless grapevines grafted on some rootstocks. J. Hortic. Sci. Ornam. Plants 2013, 5, 1-11.

36. Wunderer, W.; Schmuckenschlager, J. Grapevine grafting and wound covering. Mitteilungen Klosterneubg. Rebe Wein Obstbau Früchteverwertun. 1993, 43, 165-168.

37. Iliescu, M.; Popescu, D.; Comşa, M. Studies on quality of rootstocks in the viticultural centre Blaj. Bull. UASMV Hortic. Cluj-Napoca 2012, 69, 395-396.

38. Fan, D.; Mota, R.V.; Fávero, A.C.; Purgatto, E.; Shiga, T.M.; Souza, C.R.; Pimentel, R.M.A.; Regina, M.A. Videira 'Syrah' sobre diferentes porta-enxertos em ciclo de inverno no sul de Minas Gerais. Pesqui. Agropecu. Bras. 2012, 47, 208-215.

39. De Souza, C.R.; da Mota, R.V.; Cardozo França, D.V.; de Azevedo Pimentel, R.M.; de Albuquerque Regina, M. Cabernet Sauvignon grapevine grafted onto rootstocks during the autumn-winter. Sci. Agric. 2015, 72, 138-146. [CrossRef] 
40. Cara, S. The Influence of the Quality of the Planting Material on the Development and Productivity of the Vine. Ph.D. Thesis, Public Institution Scientific-Practical Institute of Horticulture and Food Technologies, Chisinau, Moldova, 2010.

41. Burlacu, C. Influence of the grafting wax types used for vine grafting on callusing during the forcing period and on vine quality within vine school. Lucrari Stiint. Univ. Stiint. Agron. Med. Vet. Bucur. Ser. B Hortic. 2008, 52, 102-104.

42. Teker, T.; Ulaş, S.; Dolgun, O. Effects of Scion-Rootstock Combinations on Ratio and Quality of the Potted Vine Grafts. TURKJANS 2014, 2, 1898-1904.

43. Nechita, P.; Dobrin, E.; Ciolacu, F.; Bobu, E. The Biodegradability and Mechanical Strength of Nutritive Pots for Vegetable Planting Based on Lignocellulose Composite Materials. BioResources 2010, 5, 1102-1113. [CrossRef]

44. Becker, H. Studies on the influence of the substrate on growth and output of grafts stratified in cartons. Weinb. Keller 1975, 22, 71-83.

45. Zamanidis, P.; Paschalidis, C.; Maltabar, L.; Vasiliadis, S. Effect of the Substrates on the Production of Engrafted Vine Cuttings in Heated Greenhouses. Commun. Soil Sci. Plant Anal. 2013, 44, 2488-2495. [CrossRef]

46. Warschefsky, E.J.; Klein, L.L.; Frank, M.H.; Chitwood, D.H.; Londo, J.P.; von Wettberg, E.J.B.; Miller, A.J. Rootstocks: Diversity, domestication, and impacts on shoot phenotypes. Trends Plant Sci. 2016, 21, 418-437. [CrossRef] [PubMed]

47. Bozzolo, A.; Pizzeghello, D.; Cardinali, A.; Francioso, O.; Nardi, S. Effects of moderate and high rates of biochar and compost on grapevine growth in a greenhouse experiment. AIMS Agric. Food 2017, 2, 113-128. [CrossRef]

48. Reynolds, A.G.; Wardle, D.A. Rootstocks impact vine performance and fruit composition of grapes in British Columbia. HortTechnology 2001, 11, 419-427. [CrossRef]

49. Grohs, D.S.; Almança, M.A.K.; Fajardo, T.V.M.; Halleen, F.; Miele, A. Advances in propagation of grapevine in the world. Rev. Bras. Frutic. 2017, 39. [CrossRef]

50. Muhammad, A.; Muhammad, I.; Kong, Q.; Cheng, F.; Ahmed, W.; Huang, Y.; Bie, Z. Grafting: A Technique to modify ion accumulation in horticultural crops. Front. Plant Sci. 2016, 7, 1457. [CrossRef]

51. Borsellino, V.; Galati, A.; Schimmenti, E. Every great wine starts in a grapevine nursery. Tendencies and perspective of Sicilian grapevine nurseries. In Proceedings of the Enometrics XVII, Palermo, Italy, 9-12 June 2010; p. 72.

52. Mudge, K.; Janick, J.; Scofield, S.; Goldschmidt, E.E. A history ofgrafting. Hortic. Rev. 2009, 35, 437-493. [CrossRef]

Publisher's Note: MDPI stays neutral with regard to jurisdictional claims in published maps and institutional affiliations.

(C) 2020 by the authors. Licensee MDPI, Basel, Switzerland. This article is an open access article distributed under the terms and conditions of the Creative Commons Attribution (CC BY) license (http://creativecommons.org/licenses/by/4.0/). 